Canadian Journal of Disability Studies

Published by the Canadian Disability Studies Association

Association Canadienne des Études sur le handicap

Hosted by The University of Waterloo

www.cjds.uwaterloo 
Levesque, Disability Leaders

CJDS 9.1 (February 2020)

\title{
Characteristics of Disability Leaders: An Atlantic Canada Profile
}

\author{
Dr. Mario Levesque, Associate Professor, Department of Politics and International Relations, \\ Mount Allison University \\ malevesque@mta.ca
}

\begin{abstract}
Leadership in the nonprofit sector including the disability sector has changed with the growth of the neoliberal state with governments downloading their social policy implementation role to civil society actors. The competitive climate disability nonprofits now find themselves in calls into question the leadership and skills required of their leaders. Based on 58 semi-structured interviews, this article develops a profile of Atlantic Canadian disability organization leadersexecutive directors and government disability program managers. It argues that existing leadership models insufficiently capture their operating logic and finds disability leaders increasingly transformed into a new entrepreneurial role, which challenges services provision for persons with disabilities.
\end{abstract}




\title{
Characteristics of Disability Leaders: An Atlantic Canada Profile
}

\author{
Dr. Mario Levesque, Associate Professor, Department of Politics and International Relations, \\ Mount Allison University \\ malevesque@mta.ca
}

\section{Introduction 1,2}

Nothing about us without us; this is the philosophy that guides persons with disabilities in Canada (Council of Canadians with Disabilities n.d.). But who is $u s$ ? Similarly, who represents us to decision makers in policy processes? While much is known about different types of disabilities, little is known about disability leaders and their organizations in Canada (but see Levesque 2017). This matters given the increasing trend for governments to contract program delivery with disability nonprofit groups in a competitive funding environment. This competitive environment is much different than what existed in the 1970s, 1980s and early 1990s when members of disadvantaged groups including disability nonprofits worked with decision makers hand-in-hand to address needed changes (Splane 1987). By the mid-1990s, emerging from the grips of an economic recession, and with significant deficits and mounting debt, austerity was the government's focus (Phillips 2001; LaForest 2013; Evans 2002). A review of federal funding of the voluntary sector was completed in 1994 as part of the federal government's broader Program Review cost-cutting exercise (Phillips 2001). The result was reduced federal transfers to the provinces by billions of dollars through the creation of the Canada Health and Social Transfer in 1996 (which combined Established Programs Financing for health care and post-secondary education funding; and, the Canada Assistance Plan for social assistance funding). In the first year alone, 1996, up to $\$ 300$ million in federal funding was cut, a figure that doubled in Ontario when provincial cuts were included (Miller 1998; Pedlar and Hutchison 2000). This new emphasis on contracting, accountability and reduced funding threatened the capacity of voluntary 
organizations to pursue their missions and sustain activities long-term (Levesque 2012; Coalition of Ontario Voluntary Organizations 2004; Cloutier-Fisher and Skinner 2006).

The effects on disability organizations were significant. In Ontario and British Columbia (BC), for example, diminished levels of service provision to clients ensued, particularly for those in greatest need. Organizational restructuring occurred and included significantly reduced staffing levels with a move to volunteer labour thus undermining stable services provision (Chouinard and Crooks 2008). In New Brunswick, the 1980s situation of the province funding and creating nonprofits for services delivery and automatically building in funds for new organizations every year became, in the 1990s, a situation where core funding was largely terminated, new organizations were discouraged coupled with a reduction in overall service organizations (Miller 1998; for a broader overview, see Laforest 2011).

Yet, such funding changes underscored chaotic federal leadership in the disability sector. On the one hand, the federal state was eroding support for disability organizations and downgrading its disability policy capacity, the Disability Persons Secretariat within the Secretary of State, to an information clearinghouse unit within Human Resources Development Canada (Office of Disability Issues). On the other hand, the federal government was working with its provincial partners to develop and elaborate in 1998 a vision to ensure the full participation of persons with disabilities in all facets of Canadian society as specified in In Unison (Canada 1998). It further developed short-term boutique funding programs such as the Labour Market Agreements for Persons with Disabilities and the Opportunities Fund while being a signatory to the United Nations Convention of Persons with Disabilities (see Graefe and Levesque 2010, 2006). Such measures were onerous and unworkable and progressive disability policy was stalled (Phillips, Laforest and Graham 2010; Graefe and Levesque 2010; see also Laforest 2013). 
The 2008 economic recession and the election of a Conservative government desiring a small social policy role did not help matters. The recession further strained the situation for the non-profit sector (Laforest 2013) as did the Conservative government's termination of core operational funding for disability nonprofits in 2012, the cancellation of Statistics Canada Participation and Activity Limitation Survey (PALS), the termination of the Court Challenges program (later reinstated by the Trudeau Liberal government), and the harassment of the nonprofit sector by the Canada Revenue Agency to ensure advocacy compliance (Levesque 2017; Council of Canadians with Disabilities 2010; Rae 2008).

The events of the last 30 years have left questions regarding the capacity and management of nonprofit disability groups to effectively and efficiently deliver programs and to advocate on behalf of people with disabilities (Rathgeb Smith and Phillips 2016; Levesque 2012). Note that disability groups are defined so as to include both service and advocacy organizations because the changing context within which they operate has greatly blurred the distinction. For example, advocacy groups have increasingly included services provision given the strict advocacy limitations placed on them under the former Harper government. Similarly, funding cutbacks have emphasized the advantages of charitable status in being able to issue tax receipts for donations thus greatly aiding fundraising (Levesque 2017; Keenan 2015). Given this changed environment, one question of interest is how the skill set disability leaders possess aligns with the competitive funding environment that now exists? If the fit is poor between what exists and what is required, then to whom can disability leaders turn to enhance needed skills to ensure effective program delivery? These questions are at the heart of this article and are important to governments given they are accountable for funds provided and for the inclusion of persons with disabilities in society. 
Research centred on the senior leadership of nonprofit disability organizations is scarce (but see Schalock and Verdugo 2012).3 Rather, the literature focuses broadly on leadership styles, interactions between boards of directors and their executive directors or on the general management of nonprofit organizations. The problem is twofold in that it first extrapolates lessons learned largely from the for-profit sector (e.g., Bryant 2011; Athanasaw 2003), which is missing in the nonprofit sector. Rather, disability nonprofits emphasize inclusion and fairness, among other things, items which are hard to quantify in economic terms (on this, see Baines 2015). Second, leadership research tends to group nonprofits such as churches, hospitals, educational foundations and social welfare groups as a single category (e.g., Tach and Thompson 2007; Schmid 2006). Generalizations are thus problematic given these groups' different types, sizes and functions. Combined, these issues dilute our understanding of nonprofit disability leadership.

A finer grade of analysis focused on the disability sector is needed to unravel leadership and management intricacies to improve program delivery. This is significant for the disability sector which is highly fragmented. Many disability groups exist representing diverse needs with few national groups in Canada that represent all persons with disabilities. The problem is compounded in areas that are economically challenged and with high proportions of persons with disabilities such as that found in Atlantic Canada. Needs may differ, but the common thread is how to effectively advocate and deliver programs to meet the requirements of a diverse group of people. Underpinning effective program delivery is an understanding of how leadership styles and management roles interact and are mediated by disability leaders' relations with their boards of directors. 
The nothing about us without us philosophy is important, but we need to illuminate who represents $u s$, that is, who disability leaders are, what they do and how they do it to ensure effective program delivery in the current competitive funding environment. After first reviewing the leadership literature to situate the problem, this article sketches out a profile of disability leaders in Atlantic Canada based on 58 semi-structured interviews. It finds disability leaders being transformed into a new entrepreneurial role 4 with a corresponding negative effect on those in need of disability services which challenges program implementation.

\section{Leadership Literature}

There is a growing literature on nonprofit leadership, yet it remains overly determined by the deep leadership literature in the for-profit sector. It is here where one can trace the evolution of leadership theory to its early pre-1950s beginnings which focused on identifying the personal attributes of leaders in the belief that leadership was inherent to some individuals only (e.g., Stodgill 1948). Found wanting (Hemphill 1949), attention turned to identifying leadership styles and patterns with much attention on task oriented versus more participatory leadership styles (Stogdill and Coons 1957; Halpin 1959; Likert 1961). By the 1970s, it was recognized that situational settings mediated leadership styles thus giving rise to a series of contingency theories (e.g., Fielder 1967; House 1971). Recent work integrates these theories into a process of sustaining change recognizing that leadership is a function of roles occupied, influence and context (Bass 1985; Yukl 2006). Research has focused on identifying factors that underpin transformational leadership (Popa 2012), its use (Wright and Pandey 2010) and differences when compared to transactional and collaborative styles (Trottier, Van Wart, and Wang 2008; Atwood, Mora, and Kaplan 2010; Schneider and George 2011; Fisher 2013). 
Questions remain as to the generalizability of the for-profit leadership research to the government and nonprofit sectors. If context matters for for-profit leadership styles, then likewise, the context surrounding nonprofits also matters. For example, nonprofits are often financially challenged, face high staff turnover, have fuzzy goals and report to multiple stakeholders, unlike for-profit entities which focus narrowly on the profit motive (Issa and Herman 1986; Levesque 2012; for a similar argument regarding governments, see Kellis and Ran 2012). Nonprofits have long recognized that they are different from their for-profit and government counterparts (Wilensky and Hansen 2001), differences that illuminate the need for research on nonprofit leadership (Ritchie, Anthony, and Rubens 2004; Sarros and Coope 2011).

\section{Focus on Executive Directors}

Research on nonprofit leadership is complicated by the fact that it is guided by both executive directors, the nonprofit equivalent to chief executive officers (CEOs) in the corporate sector, and their boards of directors (Howe 2004). Unlike for-profit managers (CEOs) and local government chief administrative officers who operate at a pinch point in an hourglass, halfway between their Boards or town councils and their workers and staff (see Carroll and Siegel 1999; Siegel 2010), nonprofit executive directors are located at a crossroads and have to manage up to their Boards, down to their staff and clients, out to external stakeholders such as funders and to other nonprofits as shown in Figure 1 (Mintzberg 2002). This puts a premium on leadership styles and the ability to utilize different styles depending on what direction management is directed. While top down or task-oriented leadership styles, often found in for-profit and government sectors, may be useful for managing down to staff or up to Boards, they do not necessarily elicit the best performance (Schneider and George 2011; Popa 2012). Similarly, 
collaborative or participatory leadership styles may be better for managing out to stakeholders underscoring the importance of relationship building for organizational performance (Meir and O’Toole 2003; Akkerman and Torenvlied 2011; Johansen and LeRoux 2013;) but present significant challenges for accountability (Rivenbark and Menter 2006). Our understanding of the connections between nonprofit executive directors' leadership styles, management roles and situations remains unclear and impacted by many variables including organizational size and gender (Carver 2006), as well as how such connections compare to the experiences of government program managers.

A premium is thus placed on the skills executive directors require to carry out their daily tasks — budgeting, policy development and managing staff and volunteers for program operations. It is naïve to think executive directors possess equal amounts of these skills (Rivenbark and Menter 2006; Wang and Ashcraft 2012) and ignores the importance of hands-on experience in the nonprofit sector (Suarez 2010). In short, what skills are required and how they are obtained are as equally important as how they are deployed in various leadership styles depending on the direction management is undertaken: up, down, in or out. 
Figure 1: For-Profit vs. Nonprofit Sector Management Directionality

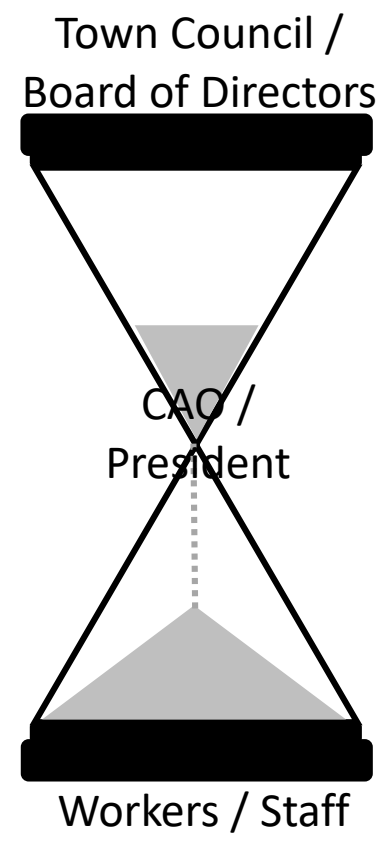

for-profit

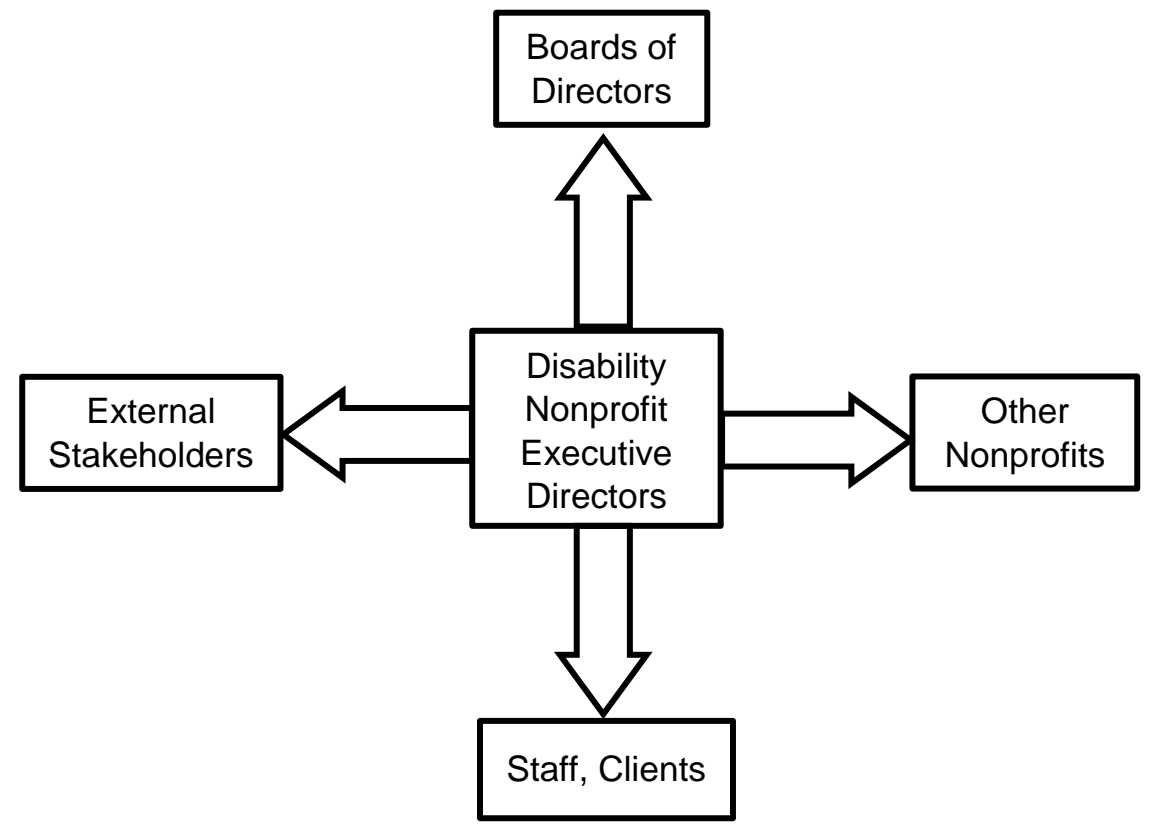

nonprofit

Description: On the left, this Figure shows an hourglass with for-profit leaders such as CAOs and Presidents located at the pinch point halfway between their Town Councils and Boards of Directors above them and workers and staff below them. On the right, is a box in the middle with arrows coming out of it in all four directions to other boxes. The centre box is where disability nonprofit Executive Directors are located. The arrow pointing up from the centre box points to where Boards of Directors are positioned. The arrow pointing down from the centre box points to where staff and clients of disability nonprofits are located. The arrow pointing to the left from the centre box points to where external stakeholders are located. Lastly, the arrow pointing to the right of the centre box points to where other nonprofits are located. The idea is that disability nonprofit Executive Directors are in the centre having to manage in multiple directions which calls into question needed management skills. This right-hand image will be reproduced below several different times to show different ratios in the management of these different relationships, with the arrows being depicted in larger or smaller sizes to denote these differences.

\section{Beyond Executive Directors}

A focus on nonprofit executive directors alone misses the mediating effect of their boards of directors given the limitations they may introduce. Boards of directors are complex entities. Their effectiveness, and the organization's, is dependent on many factors including Board tenure, 
size and composition, which often work at cross purposes (Miller, Weiss, and MacLeod 1988; Callen, Klein, and Tinkelman 2003; Guo and Musso 2007). Determining how boards of directors influence the leadership style used by executive directors is important. For example, Boards concerned with legitimation functions with a focus on organizational structures, processes and professionalization of the organization may pressure their executive directors to be task or participatory oriented in carrying out their duties. A task orientation ensures a narrow focus while participatory approaches foster inclusivity for goal realization. Both lead to enhanced stakeholder credibility. Boards preoccupied with securing funding may pressure their executive directors with being collaboratively oriented. Working with other organizations can lead to the leveraging of scarce resources to ensure program continuation or enhancement. Lastly, Boards concerned with organizational performance (effectiveness, efficiency) may exert pressure for their executive directors to be top down or task oriented where executive directors control decision making and inform subordinates of goals and expectations to ensure results are met (Abzug and Galaskiewicz 2001; Miller-Millesen 2003). The point is that boards of directors' orientations, including whether they are policy (governance) or operationally focused Boards, may not align well with the preferred leadership styles and skills of their executive directors depending on the directionality of management. Whether and how such influence is exerted in the disability nonprofit sector is unknown.

\section{Leadership in the Canadian Nonprofit Sector}

Leadership in the nonprofit sector including the disability sector has changed with the growth of the neoliberal state as governments have increasingly downloaded their social policy implementation role to civil society actors (White 2008; Levesque and Graefe 2013). Some such 
as Young and Everitt (2004) argue that civil society actors lack the broad common understanding and orientation of governments and fear the championing of narrow self-interests will ensue (see also Van Valey and Peterson 1987; Graham and Phillips 1998). Others such as Shragge (2003) argue civil society actors are ill prepared to do governments' work, and there is a need to steadfastly resist their coercion. There is merit to these arguments given the fragmentation of the nonprofit sector (Elson 2011) and its general lack of capacity which is felt unevenly across the provinces with nonprofits in economically challenged provinces such as those found in Atlantic Canada being at a greater disadvantage (Graefe and Levesque 2010; Levesque 2012).

Accepting such an analysis without further reflection is problematic and minimizes the value of the nonprofit sector. Disability organizations alone are critical sources for information, social inclusion, civic engagement and policy innovation while being valuable drivers of economic activity (Canadian Centre on Disability Studies 2002; Quarter, Mook, and Armstrong 2009). In exchange for providing this policy expertise and capacity, disability organizations receive much needed funding provided they are successful bidders on government contracts for disability services provision (Larner 2000; Wang and Ashcraft 2012). This competitive contracting climate was reinforced with the 2013 federal budget which eliminated core operational funding to 15 disability organizations in Canada and worked against their previously collaborative behaviour (Cloutier-Fisher and Skinner 2006; Canada 2013).

For disability organizations, this calls into question the leadership and skills required in this increasingly competitive and contractual environment. For governments, it requires an understanding of who they are contracting with including how that differs from government program managers in order to identify skills gaps that may then be addressed to ensure effective contracting partnerships. Expectations of disability organizations adopting neoliberal practices 
such as performance measurement as some suggest (e.g., Schalock and Verdugo 2012) are misplaced unless the skills of disability leaders and the context within which they work are addressed. It is to this task to which we now turn.

\section{Methods}

Three questions are at the heart of this research:

i. To what tasks do disability leaders allocate their time, and in what proportion?

ii. What needed key skills do disability leaders identify in carrying out their work?

iii. To what degree do disability nonprofit boards of directors influence the work of their executive directors?

The focus is on the Atlantic Canada region, an understudied area in the disability and nonprofit literature. Overall, the region is highly rural, small population wise (approximately 2.4 million people), traditionally economically challenged, and comprised of many small disability service and advocacy organizations (246 local, provincial, national; see Table 1). Combined, disability leaders may face greater pressure in carrying out their mandates. 
Table 1: Examples of Disability Nonprofits*

\begin{tabular}{|c|c|c|}
\hline Province & $\begin{array}{l}\text { No. Disability } \\
\text { Organizations } \\
\text { Identified }\end{array}$ & Examples \\
\hline New Brunswick & 51 & $\begin{array}{l}\text { - Saint John Deaf \& Hard of Hearing Assoc. } \\
\text { - } \quad \text { Autism Society New Brunswick } \\
\text { - }\end{array}$ \\
\hline Nova Scotia & 139 & $\begin{array}{l}\text { - } \text { March of Dimes Canada - NS } \\
\text { - } \text { Breton Ability Centre } \\
\text { - Central Highlands Association for the } \\
\text { Disabled (CHAD) } \\
\end{array}$ \\
\hline Prince Edward Island & 37 & $\begin{array}{l}\text { - } \\
\text { - SEI Council of People with Disabilities } \\
\text { - } \\
\text { Canadian National Institute for the Blind - } \\
\text { PEI }\end{array}$ \\
\hline $\begin{array}{c}\text { Newfoundland \& } \\
\text { Labrador }\end{array}$ & 55 & $\begin{array}{l}\text { - } \text { Cerebral Palsy Association of NL } \\
\text { - Coalition of Persons with Disabilities } \\
\text { - Learning Disabilities Association of NL }\end{array}$ \\
\hline
\end{tabular}

*For organizations with more than one location, only the main location was counted.

Interviews and a questionnaire were used to help develop a profile of Atlantic disability nonprofit leaders. Fifty-eight semi-structured interviews were conducted either in person or via telephone during 2016 and 2017. This included sixteen interviews with government disability officials such as directors, program managers and program consultants, and forty-two interviews with executive directors of disability organizations. Interviews with government officials were included in order to facilitate comparison with disability nonprofit executive directors and to identify skills gaps that need to be addressed. Their inclusion also recognizes the fact that the boundary between governments and nonprofits is porous. That is, the majority of disability nonprofit leaders surveyed had at one time or another worked in the government sector in related positions. 
Lists of government disability officials were combed from government websites (disability program and staff directories) and from suggestions from those working in the field. Similarly, a list of provincial disability organizations was developed via Google web searches and disability group websites. From these, a representative sample was selected for the interviews. For disability organizations, this included a balanced selection of groups from each province representing various disabilities following People First's (2014) disability classification to include physical (12 interviews; e.g., multiple sclerosis, muscular dystrophy, chronic arthritis, cerebral palsy, spinal cord injury, fibromyalgia), visual (3 interviews; totally and legally blind, visually impaired), hearing (e.g., deaf, hard of hearing), mental health (4 interviews; e.g., schizophrenia; mood, anxiety, eating, personality disorders; Alzheimer's, dementia, stroke), intellectual (5 interviews; e.g., Fetal alcohol syndrome, autism, Down syndrome) and learning (0 interviews; e.g., Dyslexia, dyscalculia, dysgraphia, dyspraxia, ADHD) disabilities, or a combination thereof (13 interviews).5 Lastly, disability organizations interviewed differed by whether they were primarily service (32), advocacy (5) oriented or both (5) and varied in scope from local, provincial and national (i.e., national groups with Atlantic Canadian offices). To ensure confidentially and anonymity, their names and personal information are not revealed; rather, they are referenced as NB 1 (New Brunswick 1) or NL 4 (Newfoundland \& Labrador 4). Furthermore, passages and points referenced from interviewees are representative of comments made. Questions probed tasks performed, skills required and board of directors relations. Interviews lasted on average 50 minutes.

Second, a board of directors' questionnaire was sent via regular mail (Canada Post) to all identified disability organizations where full contact information could be found. This included a letter of information detailing the project, ethics approval, the rights of the participant and 
contact details if they required further information. It also included a hard copy of the questionnaire and a self-addressed stamped envelope to facilitate the questionnaire's return. Thirty days after the hard copy questionnaire request, an e-mail was sent to follow-up with nonrespondents with the letter of information and questionnaire provided as attachments thus facilitating electronic completion. The questionnaire probed Board recruitment, composition, tenure and satisfaction levels and could be completed either by hard copy or electronically. 6 Fifty-two completed questionnaires were received from 282 surveys sent out for a response rate of $19.1 \%(\mathrm{NL}=8 / 55(14.5 \%) ; \mathrm{PEI}=8 / 37(21.6 \%) ; \mathrm{NS}=25 / 129(19.4 \%) ; \mathrm{NB}=11 / 51$ $(21.6 \%)) .7$

\section{Tasks and Skills Identification of Atlantic Canadian Disability Leaders}

\section{i. Disability Leaders: What They Do}

A wide variety of tasks were identified by disability leaders with executive directors of disability organizations identifying twice as many tasks as government disability officials (see Table 2). For executive directors, contract implementation was paramount in three of the four Atlantic provinces. As they noted, they usually get "an earful" if the service is inadequate not to mention the fact that it may jeopardize their funding (NL 3, 4; PEI 7, 11; NS 2). Yet, ensuring adequate services is hard to achieve for provincial disability groups at times. For example, in Newfoundland and Labrador, over half the province's population is located in the Avalon peninsula in the extreme southeast of the province. Outside this area, service delivery is extremely difficult given the population is scattered in numerous largely small and distant communities. As one executive director noted, while the Avalon area has about 280,000 people, the next largest region, Corner Brook on the west coast, has about 30,000 after which the 
population size drops even more dramatically in little coastal communities. Service delivery to these regions is minimal at best (NL 5). Similar situations exist in the other Atlantic provinces but not to the same degree. While a shift to online services is occurring, it is exactly these rural and distant regions that were noted as being least connected or suffering from poor quality internet connection thereby undermining online efforts (NL 5, 7; NB 1,9). The emphasis on contract implementation also demonstrates the concern disability organizations have with ensuring services are rendered to those in need.

Table 2: Ranking of Tasks Identified by Disability Leaders

\begin{tabular}{|c|l|}
\hline \multicolumn{1}{|c|}{ Rank } & Task \\
\hline Executive Directors $(\mathrm{n}=42)$ \\
\hline 1 & Contract implementation \\
\hline 2 & Relationship building \\
\hline 3 & Fundraising \\
\hline 4 & Board relations \\
\hline 5 & Staff relations / HR \\
\hline 6 & Financial / budgeting \\
\hline 7 & Planning \\
\hline 8 & Government relations \\
\hline 9 & General operations / admin \\
\hline 10 & Media relations / Public Awareness \\
\hline 11 & Advocacy \\
\hline 12 & National / federation \\
\hline 13 & Presentations \\
\hline \multicolumn{2}{|l|}{} \\
\hline Government Disability Officials ( $\mathrm{n}=16)$ \\
\hline 1 & Relationship building \\
\hline 2 & $\begin{array}{l}\text { Reporting, justifying, explaining to senior } \\
\text { management }\end{array}$ \\
\hline 3 & Internally / colleagues \\
\hline 4 & Community engagement \\
\hline 5 & General operations \\
\hline 6 & Building support with other departments \\
\hline
\end{tabular}


Fundraising and financial issues were similarly of prime importance. However, most executive directors noted the changing landscape with traditional fundraising methods being less reliable as public tastes changed over time, as well as priorities (NL 8; PEI 2, 13). Annual galas or golf tournaments are raising fewer dollars than before (PEI 4; NS 9). Complicating matters is the termination of federal funding to national disability groups. Core operational funding has been replaced with project-based funding which only provides funding for project related overhead costs leaving groups searching for funds to cover operating costs such as heat, electricity and basic office administration. The effects have been significant for national disability nonprofits with provincial/regional chapters in that they have struggled to reinvent themselves now trying to figure out how local/provincial/regional affiliations can support national offices (rather than the previous national offices supporting local/regional disability nonprofits). The point is that national offices are largely advocacy oriented, and now federally non-funded, while their chapters deliver needed services, and funded on a project-based model (NB 9; NL 3). This has caused a ripple effect with the larger national nonprofits that were previously federally funded now out in the communities actively seeking funds. Smaller disability nonprofits have been negatively impacted by this increased competition given they are in comparison often not as well established or organized. For example, larger national disability nonprofits often have designated fundraising staff $(\mathrm{NB}, 6)$. The competition for funds has also been facilitated by technological changes. For example, electronic sites such as Go Fund Me were identified as having multiplied the number of causes competing for the public dollar. This has occurred during a period of increasing precarious work - seasonal and short-term contractsleading many people to cut back on charitable giving (NL 1, 5, 7; PEI 2, 6; NB 5). For some local and regional chapters of national organizations, funding changes have forced them to 
review their operational structure with many reducing their physical office footprint in order to raise funds by renting out space (NL 5).

Financial literacy and budgeting loom large. While executive directors noted one did not have to be an accountant, they at least had to be knowledgeable enough to work through financial statements. This was easily enough done with larger disability organizations where they often had a dedicated "numbers person" with the necessary skills but was a source of added stress for smaller ones where executive directors often assumed financial planning duties which consumed almost half of their time. Many executive directors noted that while they "picked up financial know how" through practical experience, they nonetheless wished they had obtained formal training (e.g., NL 6; PEI 4, 8, 9; NS 2, 4; NB 11).

At the heart of contract implementation, fundraising and financial literacy are issues of relationship building. All executive directors noted the significant amount of time spent on working to build relationships which at times did not bear fruit until years later. This largely involved continually meeting people to educate them on their organization's work and goals and how that addressed individual and community needs. Relationship building was also multidirectional: outwards in working with sponsors and like-minded groups, upwards to their own boards of directors and government officials, and downwards to their client groups. As one executive director stated, "we are in the people business, and people come first, the rest we will figure out later" (NL 3).

Table 3 captures the multidirectionality of relationship building. We find that executive directors are largely focused downward to their staff and clients and to a lesser extent, outwards to their external stakeholders (e.g., sponsors). Managing up to their boards of directors and out to other nonprofits form very small parts of their role. Graphically, this is shown in Figure 2 where 
thicker arrows represent an increased amount of time and energy in managing specific subgroups. When broken down by province, the pattern holds with Nova Scotia demonstrating an added emphasis on managing out to external stakeholders, especially sponsors in funding relationships as interviewees revealed.7

Table 3: Task Directionality - Executive Directors, Disability Groups, Atlantic Canada

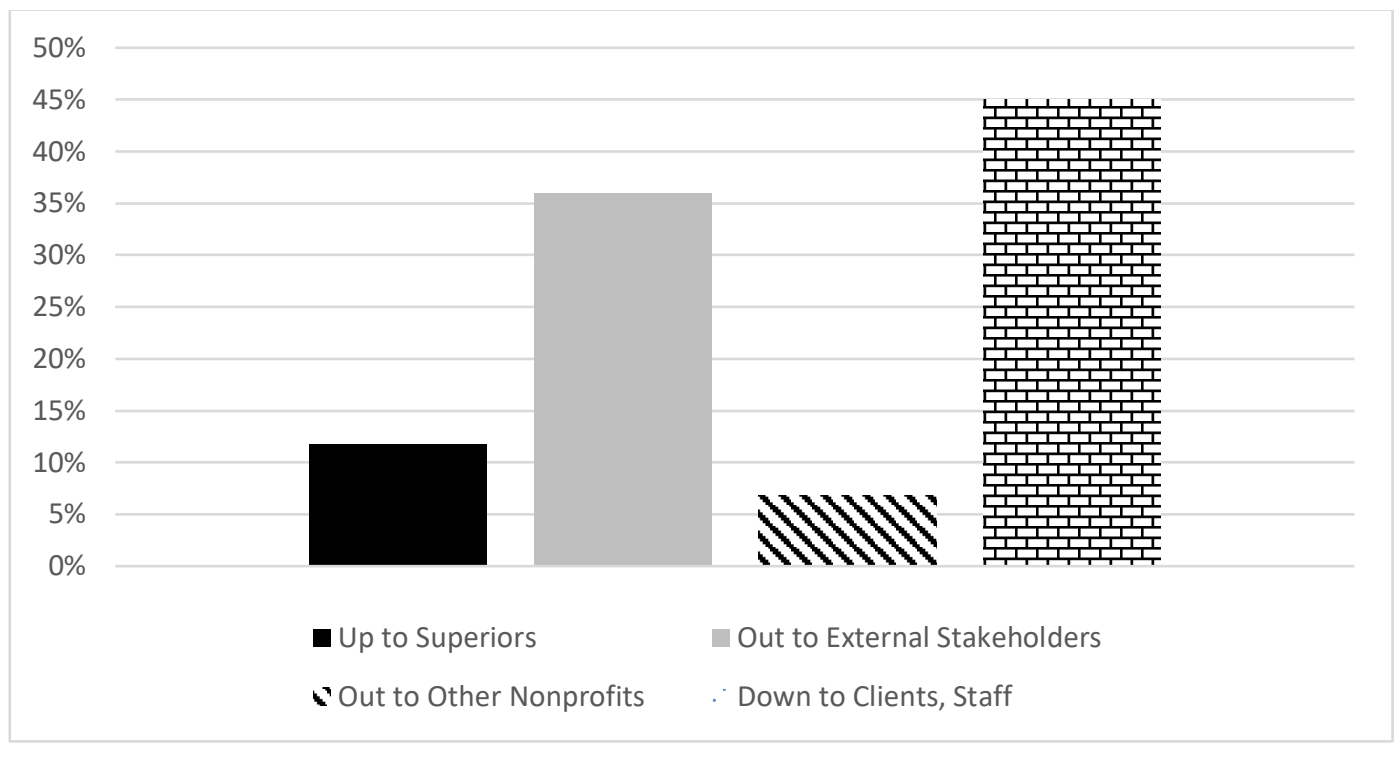




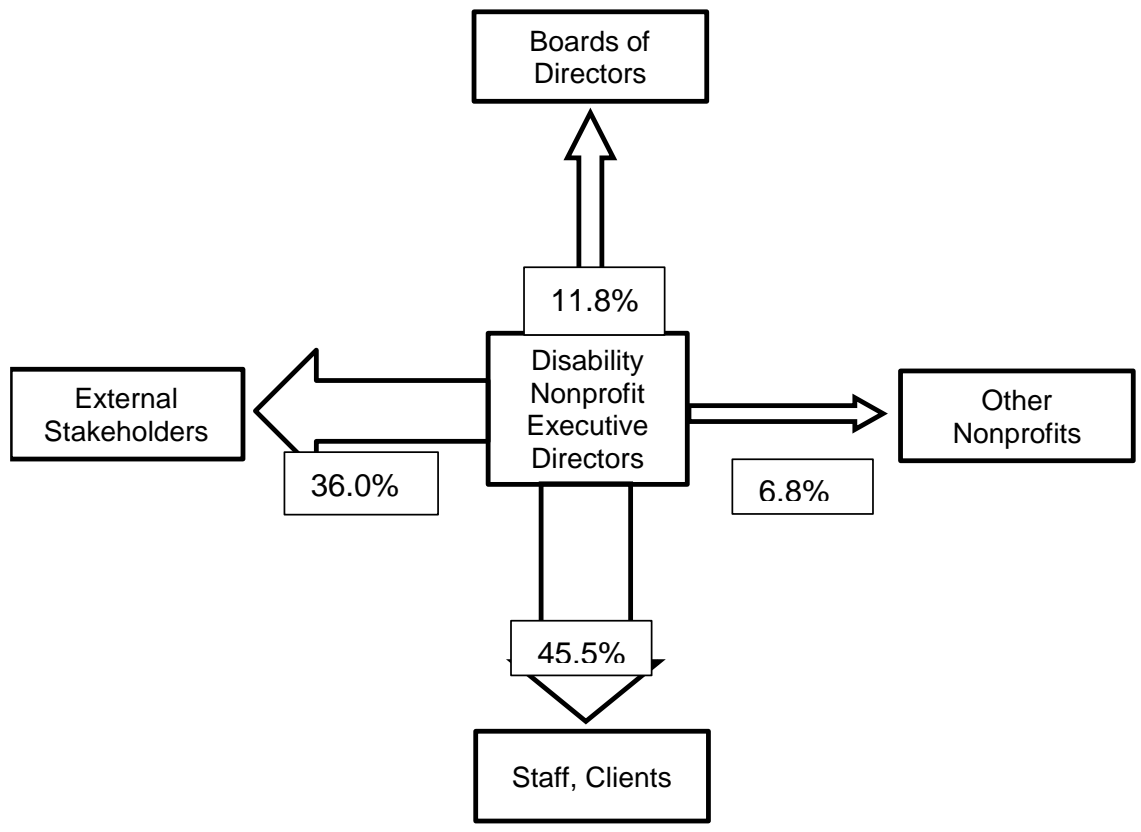

Description for Table 3 and Figure 2: Table 3 is the direction of management for the various tasks identified by executive directors. It shows that $45.5 \%$ of their time is spent managing down to clients and staff while $36 \%$ of their time is spent managing out to external stakeholders with lesser time spent managing superiors and working with other nonprofits. Figure 2 shows these management relationships graphically.

The tasks identified by government disability officials were broader in their orientation (see Table 2 above). Relationship building was still important, but twice the amount of time was spent reporting to or "managing" senior management which included convincing them why things should be done and working to overcome departmental silos. These silos are situations where departments are internally focused on carrying out their mandate and do not easily, if at all, share information and knowledge with other departments (Sanger 2008; Roberts 2011). This hinders progress on disability issues because most issues cross-cut several departments. Departmental silos were identified as the most challenging issue facing government disability officials because they had to devote a significant amount of time having to repeatedly answer how what they were asking of other departments fit their mandate and why a particular action 
should be done when it was not one of a department's main priorities. This involved a significant amount of internal preparation and work with colleagues in other departments and across units in their own department to bring decision makers together. This challenged officials with one stating "[i]t is really hard to be a really strong bureaucrat, strong advocate, and strong community person all rolled into one" (NS 3). Table 4 captures the multidirectionality of relationship building for government disability officials. Note that they spend about twice the amount of time, when compared to executive directors of disability nonprofits, in managing up to their superiors (e.g., directors, ADMs, DMs) and out to other units within their department. This is illustrated in Figure 3 where we find a greater balance in task division when compared to disability nonprofit executive directors. Results also hold when broken down on a per province basis (see Note 7).

Table 4: Task Directionality - Government Disability Program Officials, Atlantic Canada

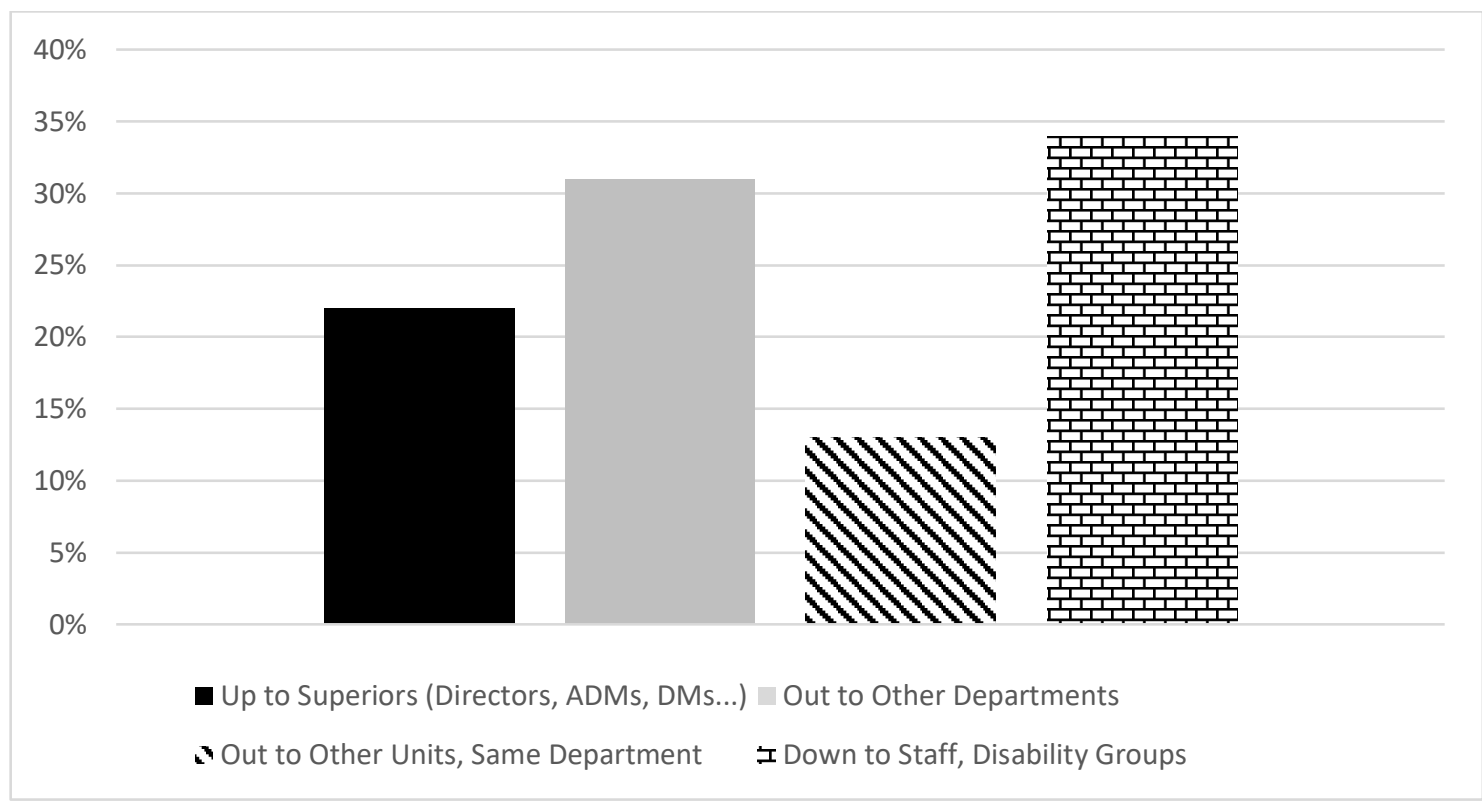


Figure 3: Task Directionality - Government Disability Program Officials, Atlantic Canada

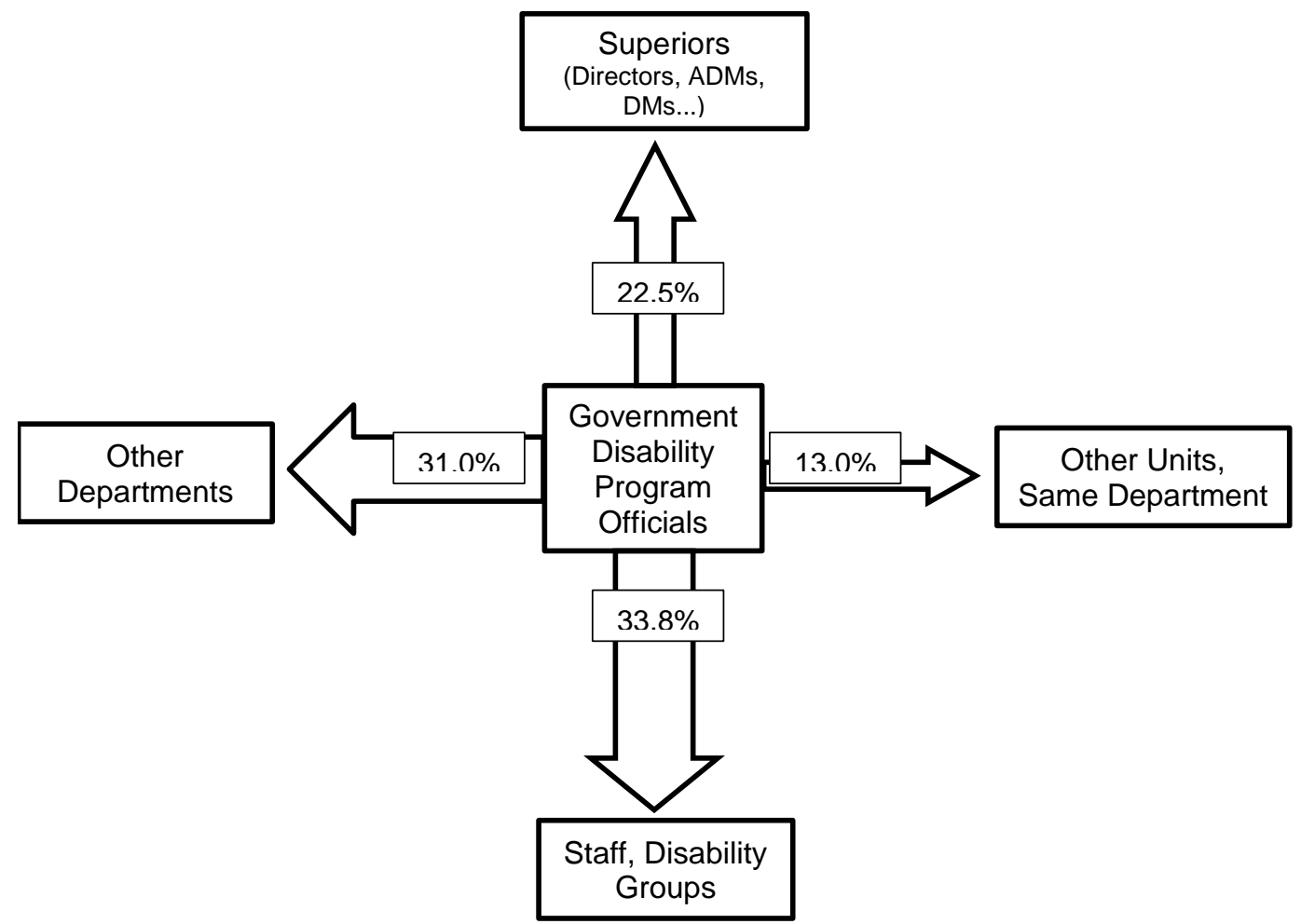

Description for Table 4 and Figure 3: Table 4 is the direction of management for the various tasks identified by government disability program officials. It shows that $33.8 \%$ of their time is spent managing down to clients (disability groups) while $31 \%$ of their time is spent managing out to other departments. Lesser time spent managing superiors (22.5\%) and to other units within their departments (13\%). Figure 3 shows these management relationships graphically.

The above results are important. For disability nonprofits, the results are consistent with the change to a competitive funding climate as the neoliberal state has become entrenched (Cloutier-Fisher and Skinner 2006; Quarter, Mook, and Armstrong 2009; Prince 2016). Executive directors are spending less time with clients and staff in order to devote more time to cultivating relationships with external stakeholders in search of stable funding to support their activities. For government disability officials, the results suggest that one's management 
direction largely reflects one's position in the government hierarchy. Government disability officials are typically low to mid-level management positions thus necessitating significant work managing superiors (directors, ADMS, DMS) as well as individuals in other units in their department in order to maintain support for disability programs and to push for program enhancements. The leadership literature is silent on the relationship between one's position and leadership directionality and styles instead focusing on leadership styles of senior management for organizational performance (e.g., Trottier, Van Wart, and Wang 2008; Wright and Pandy 2010).

\section{ii. Disability Leaders: Key Skills Identified}

Adapted from Cantrell-Bruce and Blankenberger (2015), key skills are broadly categorized as people, management, capacity and communication. A significant amount of overlap exists in skills identified between executive directors of disability organizations and government disability officials as shown in Table 5. In terms of people skills, relationship building skills were most frequently identified and emphasized. Individuals need to know how to engage diverse communities ranging from sponsors, clients, parents, employers, media and colleagues. In the words of one government disability official, it is difficult "[ $t$ ]o build relationships with people who might not have the same values or are not on the same page, who don't have the same interest, and have different career aspirations" (NL 1). Emotional intelligence, that is, being socially aware, carefully thinking before speaking, being empathetic and providing constructive feedback, was also frequently identified by executive directors. For them, this was key to understanding what they do and how they do it and was related to the need for patience, understanding, compassion and inclusion. Having an open mind, being flexible and 
willing to learn greatly helped things. Government disability officials identified similar skills to a lesser extent and the need to build trust with partners both in and out of government and the need for perseverance in navigating bureaucracy (see Table 5).

Management skills loomed large for both executive directors and government disability officials but were defined differently. For executive directors, the emphasis was twofold. First were financial matters such as fundraising, budgets and general financial literacy reflecting the need for sustained funding to ensure continued program delivery. The second was on broader management skills such as organizational, flexibility and collaborative skills reflecting the multidimensional workplace they find themselves where they often do not deliver programs on their own and draw upon other needed management skills as shown in Table 5. Government disability officials were more narrowly focused on financial literacy broadly defined, that is, understanding the impact of programs on budgets, their own and across departments while organizational structures were taken as given.

Identified skills diverge greatly in relation to capacity skills. Executive directors identified the need to be able to complete a diversity of tasks and sector specific disability knowledge. Rarely were they able to clearly focus on one item and had to, rather, balance several tasks simultaneously. This can be seen to largely reflect their emphasis on program/contract implementation. For example, numerous task-oriented skills were identified such as language and cultural competencies (especially in New Brunswick), the ability to understand contracts, problem solving and program management and evaluation. This posed challenges for executive directors, especially ones with few employees who needed to shoulder more of the work (PEI 7, 8; NB 4). For government disability officials, capacity skills surrounded the ability to analyze and synthesize material in order to justify things to senior decision makers and those in other 
departments. This necessitated a good understanding of how government worked and the ability to work to deadlines. Capacity skills identified reflected two different scales: day-to-day realities for executive directors and broader planning objectives for government disability officials.

Lastly, all interviewees identified the need for effective oral and written communication skills. In particular, disability nonprofit executive directors emphasized grant writing skills and reporting to stakeholders as key and also stressed the ability to quickly pivot depending on the audience in need. This included conducting media interviews, writing newspaper articles to educate the public on issues, working with parents and client groups to address needs and internal communications with staff and colleagues, let alone government officials and funders. For government disability officials, they stressed effectively communicating the range of services they were providing and whether it was within their mandate to provide such services to non-specialist decision makers and colleagues who faced significant pressure for scarce resources (see Table 5). As they noted, program justification, let alone expansion, to nonspecialists (e.g., Managers, Assistant Deputy Ministers, Deputy Ministers, Ministers) was challenging.

Table 5: List of Key Skills Identified - Executive Directors \& Government Officials* (see text for analysis)

\begin{tabular}{|c|c|c|}
\hline \multicolumn{3}{|l|}{ Type of Skill } \\
\hline \multirow[b]{2}{*}{ People } & $\begin{array}{l}\text { Executive } \\
\text { Directors }\end{array}$ & $\begin{array}{l}\text { Relationship building, emotional intelligence, flexibility, } \\
\text { patience, self-care, understanding, open-minded, inclusive, } \\
\text { compassionate, networking, willing to learn }\end{array}$ \\
\hline & $\begin{array}{c}\text { Government } \\
\text { Officials }\end{array}$ & $\begin{array}{l}\text { Relationship building, understanding, inclusive, emotional } \\
\text { intelligence, networking, trust, patience, perseverance, team } \\
\text { player, asks questions, empathy, good listener, flexibility, } \\
\text { open-minded }\end{array}$ \\
\hline
\end{tabular}




\begin{tabular}{|c|c|c|}
\hline \multirow[t]{2}{*}{ Management } & $\begin{array}{l}\text { Executive } \\
\text { Directors }\end{array}$ & $\begin{array}{l}\text { Fundraising, budgeting, financial reporting, organizational, } \\
\text { flexibility, collaborative, general administrative, able to } \\
\text { prioritize, staff relations, Board relations, working with } \\
\text { volunteers, visionary, negotiation, human resources, } \\
\text { mobilization, transparency, time management }\end{array}$ \\
\hline & $\begin{array}{l}\text { Government } \\
\text { Officials }\end{array}$ & $\begin{array}{l}\text { Financial literacy, Organizational, budgeting, staff relations, } \\
\text { transparency, flexibility, mobilization, asks questions, } \\
\text { facilitation, community building, accountability }\end{array}$ \\
\hline \multirow{2}{*}{ Capacity } & $\begin{array}{l}\text { Executive } \\
\text { Directors }\end{array}$ & $\begin{array}{l}\text { Diversity of work, sector knowledge, problem solving, } \\
\text { evaluation, research, program management, strategic } \\
\text { planning, creativity, language/cultural skills, understand } \\
\text { contracts }\end{array}$ \\
\hline & $\begin{array}{l}\text { Government } \\
\text { Officials }\end{array}$ & $\begin{array}{l}\text { Analysis and synthesis, work to deadlines, good } \\
\text { understanding of how government works, sector knowledge } \\
\text { (disability; disability rights), language, policy implications }\end{array}$ \\
\hline \multirow[t]{2}{*}{ Communication } & $\begin{array}{l}\text { Executive } \\
\text { Directors }\end{array}$ & $\begin{array}{l}\text { Effective oral and written communication skills for variety of } \\
\text { audiences (grant writing, reporting to stakeholders, press } \\
\text { releases, clients, sponsors, parents, schools), public speaking, } \\
\text { media }\end{array}$ \\
\hline & $\begin{array}{c}\text { Government } \\
\text { Officials }\end{array}$ & $\begin{array}{l}\text { Effective oral and written communication skills for variety of } \\
\text { audiences (colleagues, superiors, clients, stakeholders, media) }\end{array}$ \\
\hline
\end{tabular}

$*$ Italicized $=$ Most frequently identified.

\section{iii. Disability leaders and their boards of directors}

For executive directors, working with their boards of directors presented both opportunities and challenges yet evidence of Board influence was minimal. The opportunities were largely related to growth of the organization in terms of potential supporters and resources. Furthermore, Boards were important sources of information, support and guidance such as for financial reporting. Boards, however, presented challenges for executive directors to the point of being a great source of frustration by adding to their day-to-day work. As executive directors stated, time devoted to managing the Board takes away from much needed time with external stakeholders, staff and clients leading to mixed Board and organizational performance (NL 7, 8; PEI 3, 9, 14; NS 2, 3, 7; NB 4). Much depended on whether boards of directors were policy or 
operationally focused. Policy Boards develop organizational policies and monitor associated performance while operational Boards are more directly involved in the daily operations of the organizations often working alongside executive directors and staff. While a majority (55\%) of boards of directors surveyed noted that they were policy-oriented, many noted that they were in fact a hybrid model where, while they strived to be policy-oriented only, the reality was that Board members were often involved in daily activities. Most of those reporting a hybrid model were small to medium sized disability organizations possibly reflecting scale limitations.

Either way, boards of directors can consume a significant amount of an executive director's time. Boards performed a variety of functions ranging from organizational performance, fundraising and budgeting to strategic planning as shown in Table 6. This is important because the information needed for Board functions was typically supplied by executive directors such as financial details for legitimation functions (reporting). Executive directors also performed important Board member recruitment functions including identifying potential Board members, facilitating introductions and discussions between existing and potential Board members, as well as directly recruiting new Board members (see Table 7). As they noted, recruiting Board members was exhausting and challenging given the precarious funding of disability organizations, client populations that were not necessarily a priority in society, and the time commitment required to serve on Boards with fewer individuals in society inclined to serve on Boards compared to 30-40 years ago (NL 4, 7; PEI 6; NS 5, 6, 9; NB 1, 11). Such work illustrates the needed relationship building skills previously identified.

These results suggest that Boards are less influential on the leadership styles used by executive directors than what the literature suggests. Rather, the relationship was largely reversed with executive directors leading, coaching and shepherding Board members depending 
on their needs at the time. Executive directors in need of financial guidance sought out the Board member with that background. Similarly, executive directors, when needed, sought out appropriate Board members for help in working with governments and coached Board members when recruiting new members. This is also consistent with the minimal amount of time executive directors identified as working with their Boards (see Figure 2) in that Boards were used as a tool by executive directors in carrying out their work with external stakeholders, staff and clients.

Table 6: Time Allocated to Various Tasks, Board of Directors

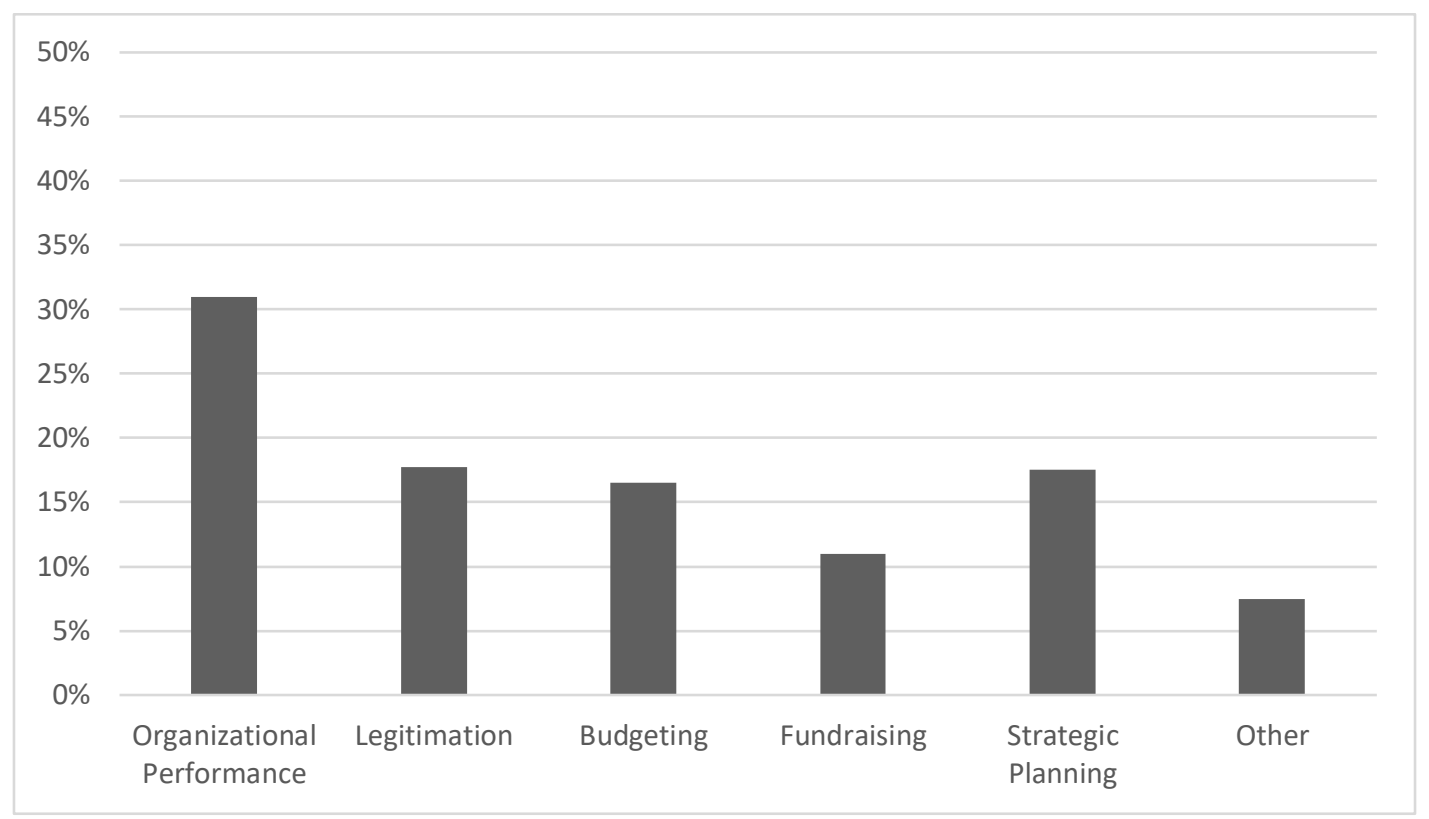

Description: From left to right, we see the average time allotted to various tasks by boards of directors. Organizational performance takes $31 \%$ of the available time, legitimation functions take $18 \%$ of the time, budgeting takes $17 \%$ of the time, fundraising takes $11 \%$ of the time, strategic planning takes $18 \%$ of the time while $8 \%$ of the time is taken up by other functions. 


\section{Table 7: Board Member Recruitment}

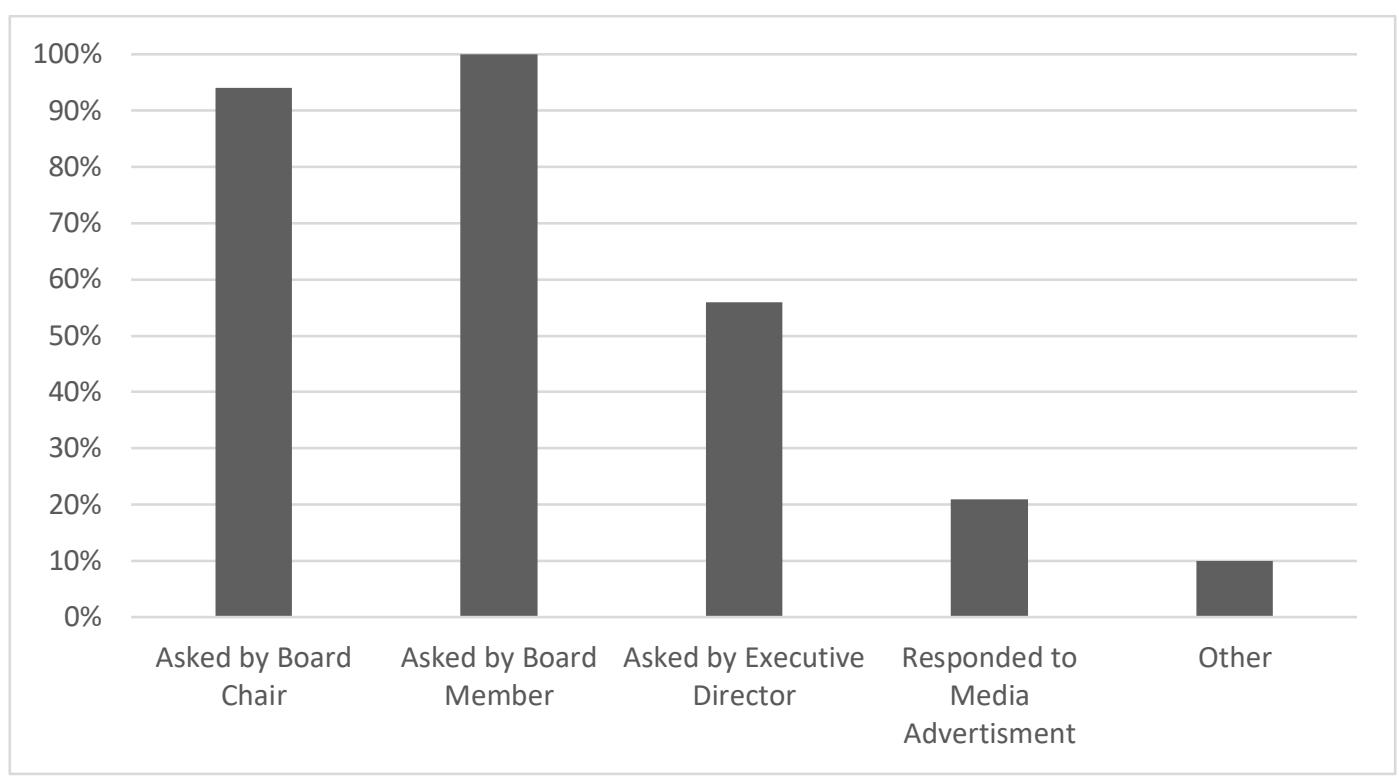

Description: From left to right, we see by whom new Board members were "officially" recruited. 94\% responded that they were recruited by the Board Chair, all responded that they were asked by another Board member, 56\% responded that they were asked by the organization's Executive Director, $21 \%$ responded that they responded to a media ad, while $10 \%$ responded that they were recruited by other means. Note that percentages do not add up to 100 because Board members were typically recruited by more than one person or multiple means.

\section{Discussion and Conclusion}

This article developed a profile of Atlantic Canadian disability leaders in terms of tasks performed and leadership styles in order to take stock of the existing skill sets and to identify gaps in needed skills so as to enhance services delivery in government-disability nonprofit partnerships. It did so in relation to government disability program officials and executive directors of disability organizations, the latter of which included a scan of their boards of directors to assess their impact. At a broad level, we are seeing disability organizations in a struggle to survive let alone thrive in a period of increasing needs for disability services. For 
executive directors, the emphasis was on contract implementation with fundraising and budgeting issues closely behind. This placed a premium on skills used-people, management, capacity and communication skills. In particular, people skills such as the ability to continually cultivate relationships with key individuals such as sponsors and government officials are critical and is at the heart of needed management skills such as fundraising and financial reporting skills. Relationship building is also key to organizational effectiveness given the need to develop staff while remaining flexible and collaborative in orientation in order to meet a diverse set of work objectives (the latter capacity skills). Cultivating relationships required effective oral and written communication skills, especially for grant writing. Far from a top down model of management as is often found in the for-profit sector, we found, in addition to an inclusive and collaborative model of management down to staff and clients, a notable outward need be similarly inclusive and collaborative in working with partner agencies and sponsors.

The above results differed slightly for government disability officials. While the hierarchical top down model of management can be found in the significant upward need to meet the need or "manage" superiors, a large and significant role exists of managing outwards to engage other departments and stakeholders in order to win support for their initiatives. Evidence of this pressure can be found in the needed capacity skills: analysis and synthesis and in having a good understanding of how government worked in addition to key relationship and effective communication skills.

Executive directors have also been challenged in the move to a competitive funding environment with many noting in interviews they wished they had had more exposure to financial issues and management. We also found executive directors challenged at times in working with their board of directors. Significant time was required to manage them given 
needed information and in filling gaps that remained to ensure the organization moved along. The results suggest that working with boards of directors was a "necessary evil" in that one could not get around it given regulations for nonprofit organizations, but the time devoted to such work necessarily took away from what could be devoted to working with client groups, staff and external stakeholders, especially for small to medium sized disability organizations.

The result is that we are left with a patchwork quilt of disability services as persons with disabilities have become customers in this neoliberal period able to purchase needed services from a number of disability organizations. However, as citizens in a democratic society, this is troubling given people are not obtaining adequate services either because they cannot afford to or because of under provision of services thereby limiting their ability to equally participate in society. This is where a focus on disability rights can help balance the playing field. It was interesting to see this point made by a government disability official (NS 3). While this may on the surface suggest a desire to minimize disability services, that is, to provide only what one is legally entitled to provide in order to meet basic rights, this was not the case. Rather, as the individual explained, the challenge was in working across departmental silos and with other units within their own department in pursuing their goals, and where the need existed to not think in terms of costs. Instead, the question to be asked was one of "What's best for the person in need of disability services?" and to then go from there. This underscored the fact that governments were poorly structured to meet the complex needs of persons with disabilities, at least until they begin using a cross-departmental person-centred approach, something which governments are poorly structured to do.

Lastly, we must question the consistency of our results with that found in the literature. To be sure, the profit motive as conceived in the for-profit sector is missing for Atlantic 
Canadian disability organizations. They were largely concerned with day-to-day operational questions, something which government disability officials increasingly recognized. Executive director management styles were also different with less of an emphasis on top-down hierarchical approaches to more collaborative and transactional approaches which reflected their being pulled in multiple directions: up to their boards of directors, out to stakeholders, out to colleagues across disability organizations and down to staff and client groups. It was also reflective of the size of disability organizations that were found with most having less than ten full-time employees while relying on a significant number of volunteers, which may be a reflection of the Atlantic Canadian situation. Boards of directors can also influence executive director management approaches but evidence to support this was hard to find in this investigation. Rather, the reverse relationship existed with executive directors busy playing an informational, coaching and shepherding role to ensure organizational functionality, something not widely discussed in the literature.

Given the multiple roles performed by executive directors of Atlantic Canadian disability organizations and the needed key skills identified, we are witnessing their transformation into "jack of all trades" with a large entrepreneurial spirit in this neoliberal period. The effects thus far on persons with disabilities of this shift have been corrosive given limits it has placed on their ability to access needed services and ability to participate in society.

\section{Notes}

1 The author thanks the Social Sciences and Humanities Research Council (SSHRC) for their generous support of this research through an Insight Development Grant (430-2016-00644), Caitlin Gallant and Anna Paradis for their research assistance, and the journal's reviewers for their helpful comments.

2 The article is based on a paper originally presented at the 2018 Atlantic Provinces Political Studies Association Annual Meetings, St. John's, Newfoundland \& Labrador, October 12-14. The author thanks Alex Marland for his constructive feedback on the paper. 
3 A growing body of work exists on disability nonprofits more broadly. For example, see Kelly 2018; Levesque 2012; Hutchinson et al. 2004; Kitchin and Wilton 2003; McColl and Boyce 2003; Neufeld 2003).

4 The need for leaders to become entrepreneurial is also found in the New Public Management literature (e.g., Coule and Patmore 2013; Paulson 2006). However, entrepreneurship is treated as an end product and not explored in relation to smaller nonprofits, the disability sector nor broken down into task directionality and accountability, related skills and Board relations, the aim of this current research.

5 Ensuring an equal distribution was not possible due to the lack of disability organizations identified for particular types of disabilities and or missing contact information. Learning disability groups contacted all declined to be interviewed.

6 It was to be completed by the Chair of the Board but on a few occasions, the executive director completed the questionnaire. Board of directors questionnaire available from author upon request.

7 Data broken down by province not shown but available from author upon request. 


\section{References}

Abzug, R., and J. Galaskiewicz. 2001. "Nonprofit Boards: Crucibles of expertise or Symbols of Local Identities?" Nonprofit and Voluntary Sector Quarterly 30 March: 51-73.

Akkerman, A., and R. Torenvlied. 2011. "Managing the Environment: Effects of Network Ambition on Agency Performance." Public Management Review 13 (1): 159-74.

Athanasaw, D. 2003. "Leadership Styles as Perceived by Career Senior Service Executives." International Journal of Public Administration 26 (10-11): 1205-34.

Atwood, M., J. Mora, and A. Kaplan. 2010. "Learning to lead: Evaluating leadership and organizational learning." Leadership \& Organizational Development Journal 31 (7): 576-95.

Baines, D. 2015. "Neoliberalism and the convergence of nonprofit care work in Canada." Competition \& Change 19 (3): 194-209. doi:10.1177/1024529415580258

Bass, B.M. 1985. Leadership and performance beyond expectations. New York, NY: Free Press.

Brown, W., and C. Guo. 2009. "Exploring the Key Roles for Nonprofit Boards." Nonprofit and Voluntary Sector Quarterly 39 June: 536-46.

Bryant, A. 2011. The Corner Office: Indispensible and Unexpected Lessons from CEOs on How to Lead and Succeed. New York: Times Books.

Bryman, A. 2004. "Qualitative research on leadership: A critical but appreciative review. The Leadership Quarterly 15 December: 729-69.

Callen, J., A. Klein, and D. Tinkelman. 2003. "Board Composition, Committees, and Organizational Efficiency: The Case of Nonprofits." Nonprofit and Voluntary Sector Quarterly 32 December: 493-520.

Canada. Federal/Provincial/Territorial Ministers Responsible for Social Services. 1998. In Unison: A Canadian Approach to Disability Issues - A Vision Paper. SP-113-10-98E. http://www.ccdonline.ca/en/socialpolicy/poverty-citizenship/income-security-reform/inunison.

Canada. Department of Finance. 2013. Jobs Growth and Long-Term Prosperity. Economic Action Plan 2013. http://www.budget.gc.ca/2013/home-accueileng.html.

Canadian Centre on Disability Studies. 2002. Disability community capacity: A framework for preliminary assessment. (Analysis Paper to HRDC, Social Policy Unit). http://www.disabilitystudies.ca.

Carroll, Barbara, and David Siegel. 1999. Service in the Field. Kingston: McGill-Queen's University Press.

Carver, John. 2006. Boards that make a difference. 3rd ed. San Francisco: Jossey-Bass Publishers.

Charlton, J. 2000. Nothing About Us Without Us: Disability Oppression and Empowerment. San Francisco: University of California Press.

Chouinard, V. and V. Crooks. 2008. "Negotiating neoliberal environments in British Columbia and Ontario, Canada: restructuring of state ${ }^{\wedge}$ voluntary sector relations and disability organizations' struggles to survive." Environment and Planning $C$ : Government and Policy 26: 173-190. 
Cloutier-Fisher, D., and M. Skinner. 2006. "Levelling the playing field? Exploring the implications of managed competition for voluntary sector providers of long-term care in small town Ontario." Health \& Place 12 March: 97-109.

Coalition of Ontario Voluntary Organizations. 2004. "Funding matters: the impact of Canada's new funding regime on nonprofit and voluntary organizations." Report on discussion at COVO Annual Meeting, 23 June. Toronto. http://www.covo.on.ca/pdfs/funding matters summary.pdf.

Coule, T., and B. Patmore. 2013. "Institutional Logics, Institutional Work, and Public Service Innovation in Non-Profit Organizations." Public Administration 91 (4): 980-997.

Council of Canadians with Disabilities. n.d. "Because It's 2018! "Nothing About Us Without Us" in Canada's New Accessibility Legislation." http://www.ccdonline.ca/en/blog/AccessLegislation.

-----. 2010. Disability Community Needs PALS in 2011. http://www.ccdonline.ca/en/socialpolicy/access-inclusion/disability-community-needspals-in-2011-19feb2010.

Drucker, P. 1990. Managing the non-profit organization: Principles and practices. New York: Harper Business.

Elson, P. 2011. High ideals and noble intentions: Voluntary Sector-government relations in Canada. Toronto: University of Toronto Press.

Evans, P. M. 2002. "Downloading the Welfare State, Canadian Style." In Diminishing Welfare, edited by G. S. Goldberg and M. G. Rosenthal. Westport: Auburn House Publishers.

Fiedler, F. E. 1967. A Theory of Leadership Effectiveness. New York: McGraw-Hill.

Fisher, L. 2013. "Transformational leadership among grassroots social service organizations." Community Development 44 (3) June: 292-304.

Golensky, M. 2011. Strategic leadership and management in nonprofit organizations: theory and practice. Chicago, Ill.: Lyceum Books.

Graefe, P. and M. Levesque. 2006. "La nouvelle gouvernance fédérale et les politiques sociales au Canada : Leçons des ententes en matière de l'intégration en emploi des personnes ayant des handicaps." Lien Social et Politiques 56: 73-86.

-----. 2010. “"Impediments to Innovation in the Canadian Social Union: The Case of the Labour Market Agreements for People with Disabilities." Canadian Public Policy 36 (1): 45-62.

-----. 2013. "Accountability in Labour Market Policies for Persons with Disabilities." In Overpromising and Underperforming? Understanding and Evaluating New Intergovernmental Accountability Regimes, edited by P. Graefe, J. Simmons and L. White. Toronto: University of Toronto Press.

Graham, K.A., and S.D. Phillips. 1997. "Citizen engagement: beyond the customer revolution." Canadian Public Administration 40 (2) June: 255-73.

Guo, C., and J. Musso, 2007. "Representation in Nonprofit and Voluntary Organizations: A Conceptual Framework." Nonprofit and Voluntary Sector Quarterly 36 June: 308-26.

Halpin, A. 1959. The Leadership Behavior of School Superintendents. Chicago: Midwest Administration Center, University of Chicago.

Hemphill, J. 1949. Situational Factors in Leadership. Columbus, Ohio: Bureau of Educational Research, Ohio State University.

Herman, R. 2005. The Jossey-Bass handbook of nonprofit leadership and management. 2nd ed. San Francisco: Jossey-Bass Publishing. 
House, R.J. 1971. "A Path Goal Theory of Leader Effectiveness.” Administrative Science Quarterly 16 September: 321-38.

Howe, F. 2004. The Nonprofit Leadership team: Building the Board-Executive Director Partnership. San Francisco: Jossey-Bass.

Hutchison, P., S. Arai, A. Pedlar, J. Lord, and F. Yuen. 2007. "Role of Canadian user-led disability organizations in the non-profit sector." Disability \& Society 22 (7): 701-716.

Issa, J., and R. Herman. 1986. "Turnover Among Nonprofit Executives: An Initial Investigation of Self-reported Causes and Consequences." Nonprofit and Voluntary Sector Quarterly 15 July: 54-9.

Johansen, M., and K. LeRoux. 2013. "Managerial Networking in Nonprofit Organizations: The Impact of Networking on Organizational and Advocacy Effectiveness. Public Administration Review 73 (2) March/April: 355-63.

Keenan, E. 2015 (January 23). "Why haven't any Harper-friendly charities been scrutinized: Keenan." Toronto Star. https://www.thestar.com/news/insight/2015/01/23/why-haventany-harper-friendly-charities-been-scrutinized-keenan.html.

Kellis, D., and B. Ran. 2013. "Modern leadership principles for public administration: Time to move forward." Journal of Public Affairs 13 (1) February: 130-41.

Kelly, C. 2018. "A future for disability: Perceptions of disabled youth and nonprofit organizations." Social Theory \& Health 16 (1): 44-59. doi:10.1057/s41285-017-0042-5

Kitchin, R., and R. Wilton. 2003. "Disability activism and the politics of scale." Canadian Geographer 47 (2): 97-115.

Larner, W. 2000. "Post welfare state governance: Towards a code of social and family responsibility." Social Politics 7 Summer: 244-65.

Laforest, R. 2011. Voluntary Sector Organizations and the State - Building New Relations. Vancouver: UBC Press.

------. 2013. Government-Nonprofit Relations in Times of Recession. Kingston: McGill-Queen's University Press.

Levesque, M. 2012. "Assessing the ability of disability organizations: An interprovincial comparative perspective." Canadian Journal of Nonprofit and Social Economy Research 3 (2): 82-103.

Levesque, M. and P. Graefe. 2013. "Not Good Enough': Canada's Stalled Disability Policy." In How Ottawa Spends, 2013-14, edited by B. Doern and C. Stoney. Ottawa: Carleton University Press.

Levesque, M. 2017. "Vulnerable Populations and the permanent campaign: Disability organizations as policy entrepreneurs." In The Permanent Campaign in Canada, edited by A. Marland, T. Giasson and A. Esselment, Vancouver: UBC Press.

Likert, R. 1961. New Patterns of Management. New York: McGraw-Hill.

McColl, M. A., and W. Boyce. 2003. "Disability advocacy organizations: a descriptive framework." Disability \& Rehabilitation 25 (8): 380-392.

McMurray, A., M. Islam, J. Sarros, and A. Pirola-Miro. 2013. "Workplace Innovation in a Nonprofit Organization." Nonprofit Management and Leadership 23 (3) Spring: 367-88.

Meier, K., and L.Jr. O'Toole. 2003. "Public Management and Educational Performance: The Impact of Managerial Networking." Public Administration Review 63 (6) November: 689-99.

Miller-Millesen, J. 2003. "Understanding the Behaviour of Nonprofit Boards of Directors: 
A Theory-Based Approach." Nonprofit and Voluntary Sector Quarterly 32 December: 521-47.

Miller, C. 1998. "Canadian Non-Profits in Crisis: The Need for Reform.” Social Policy \& Administration 32 (4): 401-419.

Miller, L., R. Weiss, and B. MacLeod. 1988. "Boards of Directors in Nonprofit Organizations: Composition, Activities, and Organizational Outcomes." Nonprofit and Voluntary Sector Quarterly 17 July: 81-9.

Mintzberg, H. 2002. "Managing care and cure - up and down, in and out." Health Services Management Research 15: 193-206.

Neufeld, A. H. 2003. "Growth and evolution of disability advocacy in Canada. In Making equality: History of advocacy and persons with disabilities in Canada, edited by D. Stienstra and A. Wight-Felske. Concord, ON: Captus Press.

Paulson, N. 2006. "New public management, innovation, and the non-profit domain: New forms of organizing and professional identity. In Organizing innovation: New approaches to cultural change and intervention in public sector organizations, edited by M. Veenswijk. Amsterdam: IOS Press.

People First. 2014. Types of Disabilities. http://www.peoplefirst4aoda.com/6-general-types-ofdisabilities/.

Pedlar A., and P. Hutchinson. 2000. "Restructuring of human services in Canada: commodification of disability. Disability and Society 15: 637-651.

Phillips, S. D. 2001. "From Charity to Clarity: Reinventing Federal Government-Voluntary Sector Relationships." The Philanthropist 16 (4): 240-262.

Phillips, S., R. Laforest, and A. Graham. 2010. "From Shopping to Social Innovation: Getting Public Financing Right in Canada." Policy and Society 29: 189-199.

Popa, A. 2012. "A Quantitative Analysis of Perceived Leadership Practices in Child Welfare Organizations." Journal of Public Child Welfare 6 (5) October: 636-58.

Prince, M. J. 2009. Absent citizens: Disability politics and policy in Canada. Toronto: University of Toronto Press.

-----. 2016. Struggling for Social Citizenship: Disabled Canadians, Income Security, and Prime Ministerial Eras. Montreal: McGill-Queen's University Press.

Quarter, J., L. Mook, and A. Armstrong. 2009. Understanding the social economy: A Canadian perspective. Toronto: University of Toronto Press.

Rae, J. 2008. "Two Steps Forward and Two Steps Backward." In The Harper Record, edited by T. Healy. Ottawa: Canadian Centre for Policy Alternatives.

Tethgeb Smith, S. and S.D. Phillips. 2016. "The Changing and Challenging Environment of Nonprofit Human Services: Implications for Governance and Program Implementation." Nonprofit Policy Forum 7 (1): 63-76.

Ritchie, W., W. Anthony, and A. Rubens. 2004. "Individual Executive Characteristics: Explaining the Divergence between Perceptual and Financial Measures in Nonprofit Organizations." Journal of Business Ethics 53 (3) September: 267-81.

Rivenbark, W., and P. Menter. 2006. "Building Results-Based Management Capacity in Nonprofit Organizations: The Role of Local Government." Public Performance \& Management Review 29 (3): 255-66.

Roberts, Nancy C. 2011. "Beyond Smokestacks and Silos: Open-Source, Web-Enabled Coordination in Organizations and Networks." Public Administration Review 71 (5) September | October: 677-93. 
Sanger, M. Bryna. 2008. "Getting to the Roots of Change: Performance Management and Organizational Culture." Public Performance \& Management Review 31 (4): 621-53.

Sarros, J., and B. Cooper. 2011. "Leadership vision, organizational culture, and support for innovation in not-for-profit and for-profit organizations." Leadership \& Organizational Development Journal 32 (3): 291-309.

Schalock, Robert, and Miguel Verdugo. 2012. A Leadership Guide for Today's Disabilities Organizations: Overcoming Challenges and Making Change Happen. Baltimore, MD: Brookes Publishing.

Schmid, H. 2006. "Leadership Styles and Leadership Change in Human and Community Service Organizations." Nonprofit Management and Leadership 17 (2) Winter: 179-94.

Schneider, S., and W. George. 2011. "Servant leadership versus transformational leadership in voluntary service organizations." Leadership \& Organizational Development Journal 32 (1): 60-77.

Shragge, E. 2003. Activism and social change: Lessons for community and local organizing. Toronto: University of Toronto Press.

Siegel, D. 2010. "The leadership of the municipal chief administrative officer." Canadian Public Administration 53 (2) June: 139-61.

Splane, R. 1987. "Social policy-making in the government of Canada, (part 1 and part 2)." In Canadian Social Policy, edited by S.A. Yelaja. Waterloo: Wilfred Laurier University Press.

Statistics Canada. 2007. Participation and activity limitation survey 2006. http://www.statcan.gc.ca/cgi-bin/imdb/p2SV.pl?Function=getSurvey\&SDDS $=3251 \&$ lang $=$ en $\& \mathrm{db}=\mathrm{imdb} \& \mathrm{adm}=8 \& \mathrm{dis}=2$.

Stogdill, R. 1948. "Personal factors associated with leadership: A survey of the literature." Journal of Psychology 26 January: 35-71.

Stogdill, R., and A. Coons. 1957. Leader Behavior: Its Description and Measurement. Columbus, Ohio: State University Press for Bureau of Business Research.

Stone, M., and F. Ostrower. 2007. "Acting in the Public Interest? Another look at research on Nonprofit Governance." Nonprofit and Voluntary Sector Quarterly 36 September: 416-38.

Suarez, D. 2010. "Street Credentials and Management Backgrounds: Careers of nonprofit Executives in an Evolving Sector." Nonprofit and Voluntary Sector Quarterly 39 August: 696-716.

Thach, E., and K.J. Thompson. 2007. "Trading places: Examining leadership competencies between for-profit vs. public and non-profit leaders." Leadership \& Organization Development Journal 28 (4): 356-75.

Trottier, T., M. Van Wart, and X. Wang. 2008. "Examining the Nature and Significance of Leadership in Government Organizations." Public Administration Review 68 (2) March/April: 319-33.

Van Valey, T., and J. Peterson. 1987. "Public service science centers: The Michigan experience." In Citizen Participation in Public Decision Making, edited by J. DeSario and S. Langton. New York: Greenwood Press.

Vladeck, B.C. 1988. "The practical differences in managing nonprofits: A practitioners' perspective.” In Educating managers of nonprofit organizations, edited by M. 
O'Neil and D. Young. New York: Praeger.

Wang, L., and R. Ashcraft. 2012. "Needs Assessment and Curriculum mapping: Enhancing Management skills of the Nonprofit Workforce." Nonprofit Management and Leadership 23 (1) Fall: 121-36.

White, D. 2008. "Can advocacy survive partnership? Representing the clients of $h$ welfare state." Paper presented to the annual meeting of ISA RC19, Stockholm, Sweden.

Wilensky, A., and C. Hansen. 2001. "Understanding the work beliefs of nonprofit executives through organizational stories." Human Resource Development Quarterly 12 (3) Fall: 223-39.

Wright, B., and S. Pandey. 2010. "Transformational Leadership in the Public Sector: Does Structure Matter?” Journal of Public Administration Research and Theory 20 (1) January: 75-89.

Young, L., and J. Everitt. 2004. Advocacy groups. Vancouver: UBC Press.

Yukl, G. 2006. Leadership in organizations. 6th ed. Upper Saddle River, NJ: Prentice Hall. 